\title{
Discovery of Lake Sinai virus and an unusual strain of acute bee paralysis virus in West African apiaries
}

\author{
Felicien AmAKPE ${ }^{1}$, Lina De SMeT ${ }^{1}$, Marleen BRUnAIN ${ }^{1}$, Jorgen RAvoEt ${ }^{1}$, \\ Frans J. JACOBS ${ }^{2}$, Wim ReYBroecKK ${ }^{3}$, Brice SinSIN $^{4}$, Dirk C. de GraAF ${ }^{1,2}$ \\ ${ }^{1}$ Laboratory of Molecular Entomology and Bee Pathology, Ghent University, Krijgslaan 281 S2, Ghent, Belgium \\ ${ }^{2}$ Honeybee Valley, Ghent University, Krijgslaan 281 S33, Ghent, Belgium \\ ${ }^{3}$ Technology and Food Science Unit, Institute for Agricultural and Fisheries Research (ILVO), Melle, Belgium \\ ${ }^{4}$ Laboratory of Applied Ecology, University of Abomey-Calavi, Abomey-Calavi, Republic of Benin
}

Received 2 January 2015 - Revised 10 May 2015 - Accepted 1 June 2015

\begin{abstract}
Samples of bees and honey from 101 apiaries were collected in the West African Republic of Benin. Visual inspection revealed high Varroa destructor and Aethina tumida infestations and low Oplostomus fuligineus infestations. A pathogen screen based on bacterial/fungal cultures or microscopic examinations revealed the absence of American and European foulbrood, chalkbrood disease, acariosis and nosemosis. However, 13 bee samples $(15.47 \%)$ were found to be infected by viruses as determined by PCR-based techniques. Acute bee paralysis virus (ABPV; $8.33 \%$ ) and Black queen cell virus $(4.76 \%)$ were the most common. From the former we found a strain with an unusual molecular signature of the capsid region, which was taxonomically positioned between ABPV and Israeli acute paralysis virus. We also discovered Lake Sinai virus (LSV; 3.57 \%) for the first time in Africa. Eight honey samples collected in regions where cotton was cultivated were subjected to multi-residue and quality control analyses.
\end{abstract}

honey bees / diseases / parasites / viruses / pesticide residue

\section{INTRODUCTION}

Beekeeping is a human activity that has been carried out since the times of Ancient Egypt. Today it represents an important economic activity in many parts of the world because of the honey that bees (Apis mellifera) produce, whereas the economic value of the pollination services is many times higher. In fact, more than $60 \%$ of the 1330 cultivated crop species depend on bee pollination, which is also known to improve crop

Electronic supplementary material The online version of this article (doi:10.1007/s 13592-015-0372-z) contains supplementary material, which is available to authorized users.

Corresponding author: D. Graaf,

Dirk.deGraaf@UGent.be

Manuscript editor: Stan Schneider quality (Jacobs et al. 2006; Klein et al. 2007; Roubik 1995; Kearns et al. 1998; Hopping et al. 1993). The contribution of honey bees to the Gross Domestic Products is estimated to more than $\$ 15$ billion per year in the United States and $£ 200$ million per year in the United Kingdoms (Morse and Calderone 2000).

In poor countries such as the Republic of Benin, beekeeping is one of those rare niche activities that needs little investment, but nevertheless provides substantial income to local people. Developing this activity could then be one of the most efficient strategies for combating poverty in such areas. But in addition to the weak management system that limits hive product yields, beekeeping in developing countries is negatively impacted by numerous pests, and the access to potential markets is hindered by pesticide residues that affect honey quality (OIE 2009). Thus, it 
becomes urgent and compulsory to document bee health status and the potential honey residues in order to make sure the country fits the international market standards as far as hive products are concerned. The present study was undertaken as part of a larger project aimed at improving the living standards of local beekeepers and extending their working field. In a previous study, we performed a nationwide categorisation of the land based on melliferous plants, in order to determine and evaluate the different beekeeping regions of the country (Amakpe et al. 2015). Here, we present data of selected bee pests and residues that could affect honey quality, in additional to other quality parameters.

The health status of African honey bees is far less characterised than those of their European and North American counterparts. In the last comprehensive review of world bee health, information from Sub-Saharan African countries was mostly lacking or incomplete, and was mainly based on predators such as ants, mice and the widespread small hive beetle Aethina tumida (Ellis 2004). Since then, the situation has hardly improved. New data on the prevalence of the bee lice Braula coeca in East African Ethiopia became available (Gidey et al. 2012). A screen for the most common bee viruses in Uganda revealed for the first time the presence of Black queen cell virus (BQCV). The pathogen load of South African stationary and migratory Apis mellifera scutellata apiaries were compared (Strauss et al. 2013), and recently, a comprehensive nationwide survey was conducted in the East African Kenya in order to assess the presence of parasites, viruses and pesticide contaminants (Muli et al. 2014). However, data on the pathogen load of most West African countries, including the Republic of Benin, are still missing.

In order to fill that gap, we conducted a nationwide pathogen screen focusing on bacterial, fungal and viral bee pathogens and other parasites and pest species. In parallel, honey samples were examined for the presence of pesticide residues and other quality parameters. With respect to the viral agents, we at first utilised the BeeDoctor multiplexing tool, which allowed us to screen for up to eight viruses or virus complexes simultaneously (De Smet et al. 2012). This diagnostic tool is based on multiplex ligation-dependent probe amplification (MLPA) technology and permits minor sequence variations of the target nucleic acid. Thus, it offers the opportunity to detect virus strains with minor deviations when compared to the reference sequences. We subsequently confirmed viral presence by RT-PCR followed by amplicon sequencing.

\section{MATERIALS AND METHODS}

\subsection{Study area}

The honey bee samples were collected from established apiaries throughout the entire Republic of Benin. It is a West African country located in the Guinean Gulf that shares borders with the Republic of Togo to the west, the Republic of Niger to the north, the Republic of Burkina-Faso to the northwest, the Federal Republic of Nigeria to the east and the Atlantic Ocean to the south. Beekeeping is mainly based on natural swarms from the neighbourhood of the beekeeper, and no bee colony introduction in the country was reported until now. The most common hives in use are the Kenyan top bar hives (KTBH), and very few people use frame hives. The average number of hives per beekeeper is five, with a maximum of 20 hives per beekeeper in a few apiaries located in the departments of Borgou, Donga and Zou (Amakpe 2008). The studied colonies were obtained from trained beekeepers that received hives in 2010 and 2011 from a supporting local NGO 'Cercle Nature et Développement' (CENAD$\mathrm{NGO}$ ) in the south and the centre of the country, and from the 'Centre Intégré d'Apiculture Tropical' (CIAT$\mathrm{NGO}$ ) in the north. The hives were baited and allowed to be freely colonised by natural swarms in order to be sure that the bees really belonged to the surroundings of the apiaries and bear the signature of the natural environment.

AS for dealing with the pesticide residues in the country, cotton is the main annual crop that uses pesticides. We assumed that the different pesticides in use in the country could be found as residues in the honey collected from the areas where cotton is intensively cultivated. We then select eight hives distributed in the different agricultural regions of the country. 


\subsection{Sample collection}

Samples were collected from 101 apiaries established all over the country at an average distance of $40 \mathrm{~km}$. At the time of sample collection, all the hives bore colonies of a minimum age of 6 months old. The colonies also had at least one full mature honeycomb, enough caped larval combs and at least eight combs in total. The collection period ran from February 2012 to December 2012. The distribution of the hives within the country is shown in Figure 1.

At each apiary, approximately 100 bees were collected from the inner parts of one hive with an adapted hand aspirator and immediately put in $90 \%$ alcohol. At the same time, a piece of mature honeycomb was cut and put in a sealed 0.25 -L jar. Pieces of worker brood and drone brood were also taken for immediate examination for mites (see further). The collected bees and honey were kept at the local room temperature (average of $32{ }^{\circ} \mathrm{C}$ ) until they were brought to the laboratory in Ghent (Belgium) in February 2013. From then on, they were stored at $5{ }^{\circ} \mathrm{C}$ for about a month until the start of the analyses. Sample codes refer to the bee hives.

\subsection{Testing for bacterial pathogens}

Honey samples were tested for the presence of the ethiological agents of American foulbrood (Paenibacillus larvae) and European foulbrood (Melissococcus plutonius) by cultivation. For American foulbrood, $5 \mathrm{~g}$ of honey was diluted with an equal amount of PBS, heated to $50{ }^{\circ} \mathrm{C}$, vigorously shaken and then centrifuged at $3000 \mathrm{rpm}$ for $30 \mathrm{~min}$, after which the supernatant was discarded (de Graaf et al. 2006). The pelleted sediment was re-suspended in $150 \mu \mathrm{L}$ of PBS, heat treated $\left(80{ }^{\circ} \mathrm{C}\right.$ for $\left.10 \mathrm{~min}\right)$ in order to kill the vegetative stages of contaminating bacteria, and plated out on MYPGP-agar with $0.1 \%$ of two antibiotics (pipemidic acid and nalidixic acid). After at least 4 days of incubation at $37^{\circ} \mathrm{C}$ under aerobic atmosphere, plates were inspected for bacterial colonies and compared with a positive plate. Suspicious colonies were further characterised by the catalase test and Gram staining.

The test for European foulbrood was mainly performed as mentioned above, but we omitted the heat treatment steps and the sediment-PBS mixtures were plated out directly on an appropriate medium (Bailey solid medium; Bailey and Collins 1982) and incubated under anaerobic conditions at $37^{\circ} \mathrm{C}$ for at least 4 days, and then compared with a positive control plate. Again, suspicious colonies were further characterised by Gram staining.

\subsection{Testing for fungal pathogens}

Honey samples were also tested for the spores of Ascosphaera apis, the ethiological agent of chalkbrood disease. Similarly as for foulbrood testing, the honey samples were diluted in PBS, centrifuged and the sediment-PBS mixture was plated out (without heat treatment) on an appropriate medium (solid Sabouraud medium). Incubation was done at $28^{\circ} \mathrm{C}$ for $72 \mathrm{~h}$ and suspicious fungal growth was further examined microscopically and compared with a positive control sample.

\subsection{Parasitic examination}

At the apiary, bee hives were examined for the presence of Varroa destructor, including both the phoretic (on workers bees and drones) and reproductive mites (opening approximately 50 worker bee and drone brood cells). The presence of the pest species Aethina tumida (small hive beetle) and Oplostomus fuligineus (large hive beetle) was also recorded and was based on the finding of their eggs, larvae or adults in the inspected hives.

In the laboratory, adult bees were examined for the presence of the tracheal mite (Acarapis woodi) and Nosema spores. For the former, we dissected the thoraces of ten bees per sample in order to expose the tracheas, which were further examined microscopically for the presence of mites (Denmark et al. 2000; Fakhimzadeh 2001). For finding Nosema spores, we homogenised whole abdomins by mechanical beating in PBS at maximum speed. Twenty microliters of the obtained suspension was examined under the microscope at a magnitude of $400 \times$.

\subsection{Initial screening for viruses with the BeeDoctor}

As the bee samples were kept in alcohol for 4 to 12 months, tissue homogenisation and RNA isolation was preceded by three wash steps of ten bees per sample in PBS at $5{ }^{\circ} \mathrm{C}$ under continuous agitation in an endover-end rotator for 72 and 24 (twice) hours, respectively. Then the bees were transferred to $4 \mathrm{~mL}$ of PBS and 


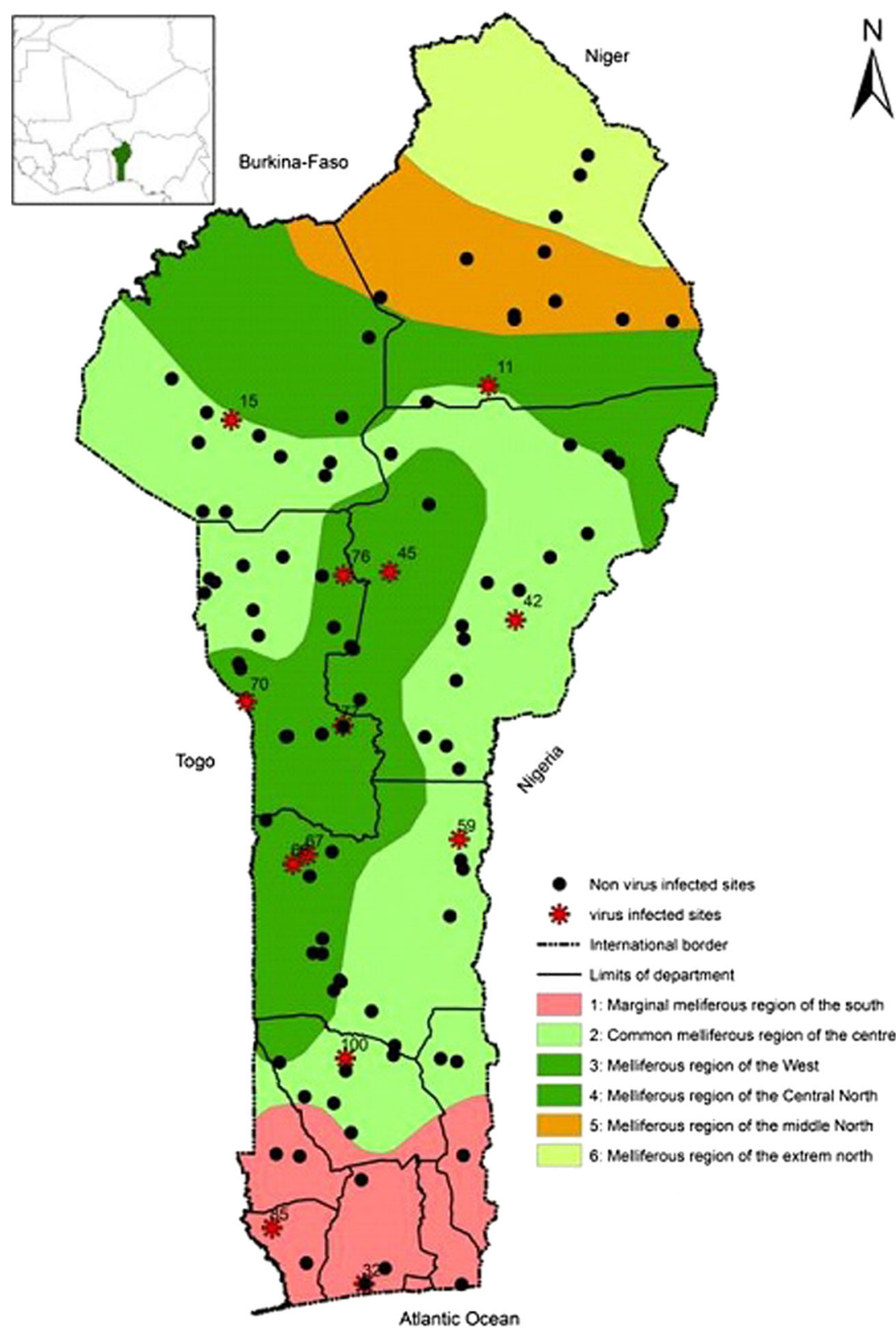

Figure 1. Map of the Republic of Benin with the locations of the apiaries that were investigated for the pathogen screening. Black dots represent apiaries where no viruses were found; red stars represent the virus infected apiaries. The background coloration represents the different silvo-melliferous regions (Amakpe et al. 2015).

grounded by mechanic agitation in a TissueLyser (Bertin Technologies, Saint Quentin en Yvelines Cedex, France) for $10 \mathrm{~min}$ at maximum speed in the presence of $100 \mu \mathrm{L}$ of zirconia beads and two metal stainless beads (De Smet et al. 2012), and thereafter stored at $-80{ }^{\circ} \mathrm{C}$ until further use. Once they were thawed, we performed two centrifugation steps, transferring the supernatants to a clean vial each time. Then RNA was extracted from $140 \mu \mathrm{L}$ of supernatants with the QiaAmp Viral RNA Mini 
Kit (Qiagen, Frederick, MD, USA) according to the manufacturer's instructions.

BeeDoctor, an MLPA-based method for simultaneous detection of multiple bee viruses, was used in its mode to detect eight honey bee viruses or virus complexes: Chronic bee paralysis virus (CBPV), Deformed wing virus (DWV) complex, ABPV complex, BQCV, Slow bee paralysis virus (SBPV), Aphid lethal paralysis virus (ALPV) strain Brookings, Big Sioux River virus (BSRV) and Lake Sinai virus (LSV) complex (Ravoet et al. 2013). All probes were synthesised by Integrated DNA Technologies (Leuven, Belgium). The tests were done with $1 \mu \mathrm{L}$ of starting material (RNA solution). Reagents typical for the MLPA reactions were purchased from MRC-Holland. And finally, amplicon lengths were determined by $4 \%$ high resolution agarose gel electrophoresis. In order to validate putative negative results, samples were re-analysed by MLPA in a setting with the reference gene $\beta$-actin (for probe design, see De Smet et al. 2012).

\subsection{Reverse transcriptase-PCR and sequencing}

The confirmation of virus presence was done by reverse transcriptase-PCR (RT-PCR) followed by sequencing. First, RNA $(5 \mu \mathrm{L})$ was reverse transcribed using the RevertAid ${ }^{\mathrm{TM}}$ First Strand cDNA Synthesis Kit (Thermo Scientific, Waltham, MA, USA) with random hexamer primers according to the manufacturer's instructions. Subsequent PCR reactions were done in a mixture of $1.5 \mathrm{mM} \mathrm{MgCl} 2,0.2 \mathrm{mM}$ dNTP, $1.25 \mathrm{U}$ Hotstar Taq DNA polymerase (Qiagen, Frederick, MD, USA), $1 \mu \mathrm{L}$ cDNA product and the appropriate primer set $(2 \mu \mathrm{M}$ of each primer; primer sequences can be found in Ravoet et al. 2014). Samples positive for the ABPV complex were reanalysed with primers covering parts of the capsid gene specific for ABPV, IAPV and Kashmir bee virus (KBV), designed by Singh et al. (2010). Positive and negative controls were always included. All PCR products were electrophoresed in $1.4 \%$ agarose gels, stained with ethidium bromide and visualised under UV light. The IAPV amplicon was cloned using the TOPO TA Cloning Kit for Sequencing (Invitrogen, Waltham, MA, USA). Amplicons were sequenced on an ABI 3130XL platform using virus-specific primers or M13 primers. These sequences were analysed using Geneious R7. The deviating ABPV sequences were deposited to GenBank as KP025950-KP025952.

\subsection{Phylogenetic analysis}

Similar amino acid sequences were downloaded in Geneious R7 using a blastp search. Sequences with more than $40 \%$ pairwise identity were MUSCLE aligned and trimmed. The best fitting maximum likelihood (ML) model was selected using the Bayesian information criterion (BIC), as implemented in MEGA6. Phylogenetic trees were inferred via ML using PhyML 3.0 (Guindon et al. 2010), with the JonesTaylor-Thornton amino acid substitution model with a discrete gamma distribution $(\mathrm{JTT}+\mathrm{G})$ and approximate likelihood ratio test non-parametric branch support based on a Shimodaira-Hasegawa-like (aLRT SH-like) procedure.

\subsection{Pesticide residue and honey quality analysis}

Eight honey samples from the two main regions of pesticide use were retained for multiresidue and honey quality analyses. Three apiaries were selected from the south cotton belt regions and were located in the district of Djidja, Ouesse and Ketou; two apiaries were selected in the cotton belt of north of the country in the district of Banikoara and N'dali, and three apiaries were selected in the marginal cotton region in the district of Toukountouna (in the north) and Comè and Lokossa in the South of the country (Figure 2). The samples were analysed for the presence of 293 organochlorine and organophosphorous compounds by LC-MS/MS and GC-MS/ MS at Intertek Food Services GmbH (Bremen, Germany) with a limit of quantification (LOQ) of $10 \mu \mathrm{g} / \mathrm{kg}$ for most pesticides except for fenthion, iprovalicarb and pirimicarb (LOQ ranging from 20 to $70 \mu \mathrm{g} / \mathrm{kg}$ ). The honeys were also analysed at the Institute for Agricultural and Fisheries Research (ILVO) for the following honey quality parameters: moisture (refractometric method), electrical conductivity, specific rotation, hydroxymethylfurfural (after White) and diastase activity (Phadebas), following Harmonised Methods of the International Honey Commission (IHC 2009). The quality results were interpreted in respect to the European legislation (Directive 2014/63/EU of the European Parliament and of the Council). 


\section{RESULTS}

The outcome of the pathogen screen is summarised in Table I. In fact, we were unable to detect any of the bacterial and fungal pathogens, nor the parasites Nosema spp. or A. woodi. The search for viruses yielded a small number of positive cases. The initial screening with the BeeDoctor produced 17 suspicious results, 14 of which could be confirmed by the subsequent RTPCR analyses. Only the faint bands for CBPV (sample 76), LSV (sample 95) and SBPV (sample 99) remained unconfirmed. From the seven samples that were positive for ABPV complex in the BeeDoctor, six could be assigned to ABPV and one to IAPV in the confirmative RT-PCR. Remarkably, when the sequencing data of the latter became available, we found that it clustered more to the ABPV clade than to the IAPV clade (Figure 3). We therefore considered it as an unusual ABPV strain with an intermediate molecular signature. In addition, we found for the very first time LSV in samples from the African continent (samples 32, 67 and 77) and four samples that were positive for BQCV (samples 11, 32, 45 and 78). Here again, RT-PCR amplicons were additionally subjected to sequencing in order to confirm the virus status of the samples. Taking into account the number of negative results that could be validated (only 71 on 77 examined samples), our study revealed a prevalence of $8.33 \%, 3.57$ and $4.76 \%$ for ABPV, LSV and BQCV, respectively.

Approximately half of the examined bee hives were Varroa infested (48 hives) (Table S2), and most remarkably, of the 13 hives that were virus positive, only six were found to be infested with Varroa mites. The small hive beetle was almost omnipresent, with 90 infested hives. The large hive beetle was much less prevalent, with only 13 infested hives.

With respect to the honey quality, in two samples (sample 14: $93.5 \mathrm{mg} / \mathrm{kg}$; sample 85: $231.6 \mathrm{mg} / \mathrm{kg}$ ) the HMF concentration exceeded the European standard of $80 \mathrm{mg} / \mathrm{kg}$ for honey from regions with a tropical climate (Table II). In two samples (sample 80: 6.1 U/g; sample 88: $2.7 \mathrm{U} / \mathrm{g}$ ), the diastase activity was below the standard of $8 \mathrm{U} / \mathrm{g}$. Finally, the moisture content in sample 93 was $20.2 \mathrm{~g} / 100 \mathrm{~g}$, exceeding the general standard of $20 \mathrm{~g} / 100 \mathrm{~g}$. All other results were in line with European honey quality legislation (Directive 2014/63/EU). All honey samples were also free from residues of 293 different organochlorine and organophosphorous pesticides.

\section{DISCUSSION}

Failure to find the ethiological agents of American and European foulbrood was not unexpected. Indeed, although both diseases have a broad distribution, they are under-represented in SubSaharan Africa, especially in the western part. Clinical outbreaks of American foulbrood occur in South Africa (Human et al. 2011), but the limited information from the western part of the continent only discusses contaminated honey samples (Brødsgaard and Hansen 2003). Human and colleagues (Human et al. 2011) state that the absence of clinical AFB cases in Sub-Saharan Africa can at least partially be explained by the fact that African honey bees, Apis mellifera scutellata, abscond more frequently from their hive when disturbed. Moreover, according to Sanford (2003), weak colonies and absconded hives are rapidly invaded by SHB and wax moth, which totally destroy the broods and combs, and thus stop further spread of the foulbrood diseases. The absence of chalkbrood disease is also in line with expectations, as this disease has only been reported in one country in Sub-Saharan Africa, i.e., South Africa, which has almost the same apicultural practice as in Western and Asian countries (Ellis and Munn 2005). There are some older (Fries 2002) and recent (Muli et al. 2014) reports on the occurrence of nosemosis in Sub-Saharan Africa, though they are not numerous from the west. The closest country where Nosema spp. have been found is Niger (Matheson 1996). Moreover, the detection limit of the microscopic examination that we performed is much lower than that of the PCR test performed in the bee health study in Kenya (Muli et al. 2014). However, the purpose of the present study was to identify putative threats for beekeeping practice in the different beekeeping regions of the Republic of Benin. We believe that based on what we found, honey bee diseases do not represent a major threat for beekeeping practices in this country. In fact, the 


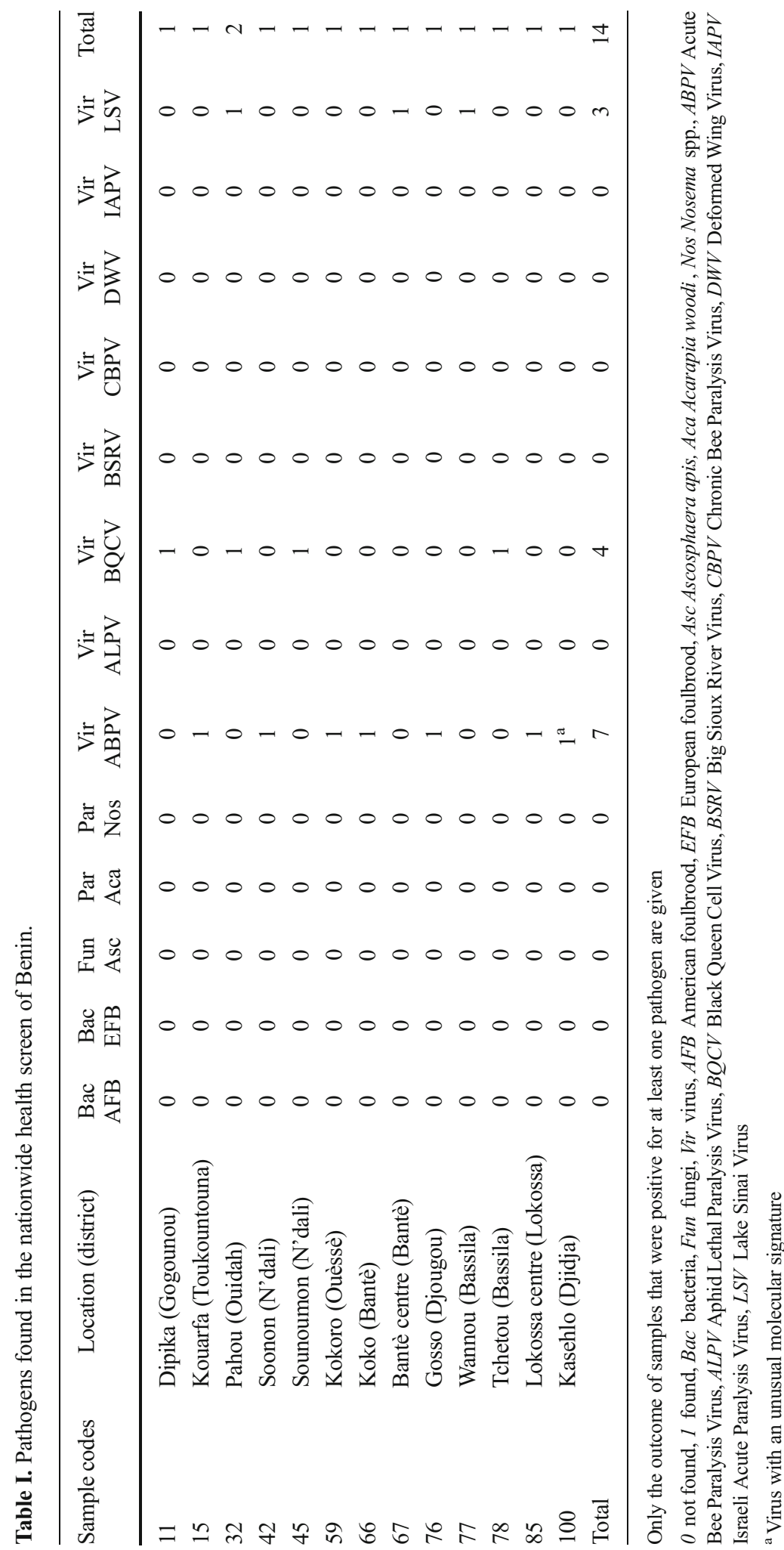




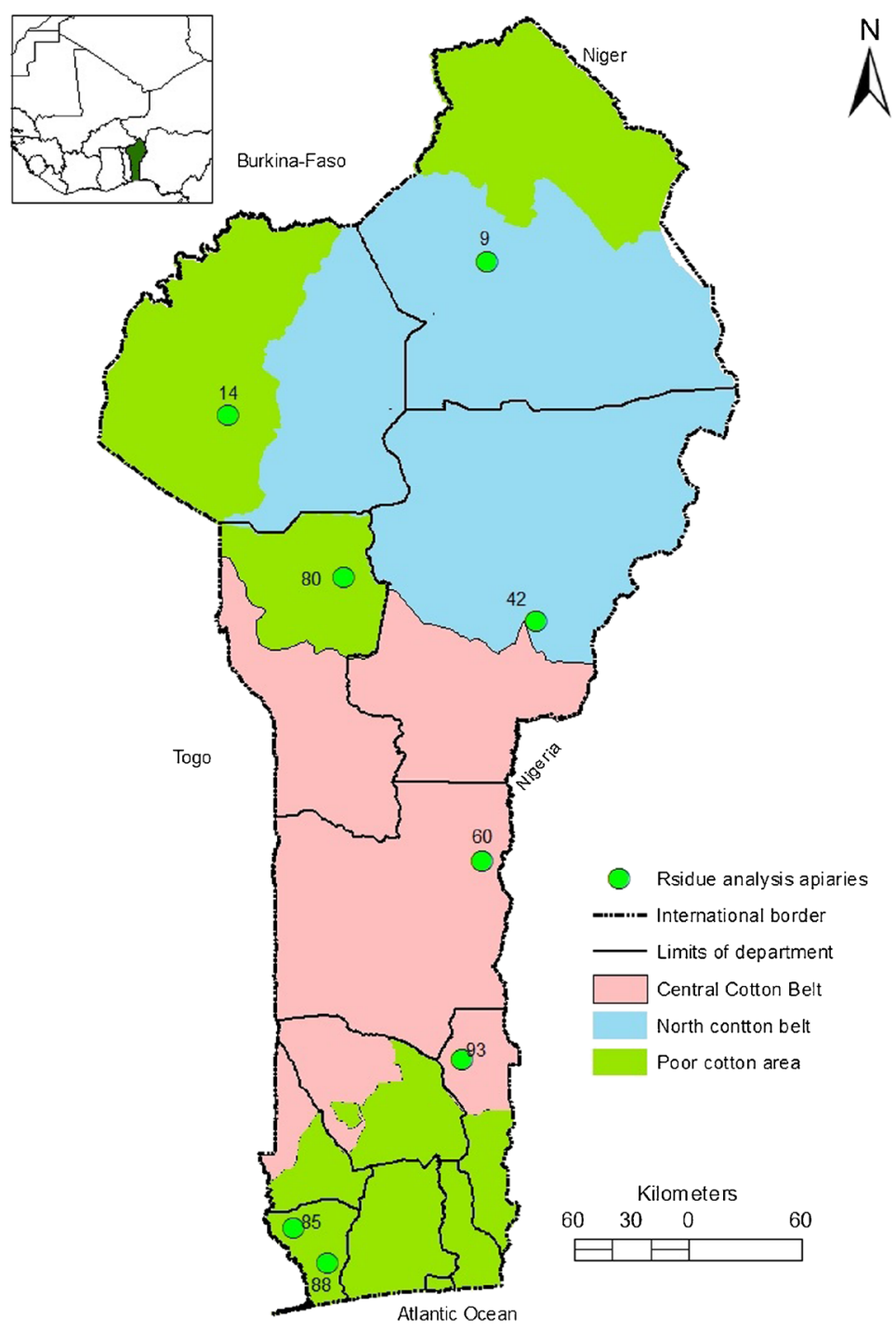

Figure 2. Map of the Republic of Benin with the locations of the apiaries that were investigated for pesticide residue analyses of honey. Green dots represent the apiaries from which honey was analysed. The background coloration represents the different agricultural regions of cotton production.

poor development of beekeeping where hives density is very low and the widespread management system in which the colonies are renewed each year reduces cross infection or infestation. In addition to this situation, the native Apis mellifera adansonii subspecies is known to be very defensive and hygienic. It also absconds a lot and the abandoned combs or broods are destroyed by SHB and wax moth invasion, as explained above (Adjare 1990; Sanford 2003), reducing the probability of establishment of or outbreak of diseases.
Unfortunately, the Varroa mite and the small hive beetle were highly rooted in the apiaries of this country, as in the entire tropical area (Paraïso et al. 2011). But this apparently has no impact on the occurrence of bee viruses, as in our study bee viruses were found even more frequently in apiaries where the Varroa mite was lacking. In fact, with only 13 virus-infected apiaries found nationwide, corresponding to a prevalence of $15.47 \%$ (only the validated data were taken into account), the viral load of bee colonies in Benin is still very 


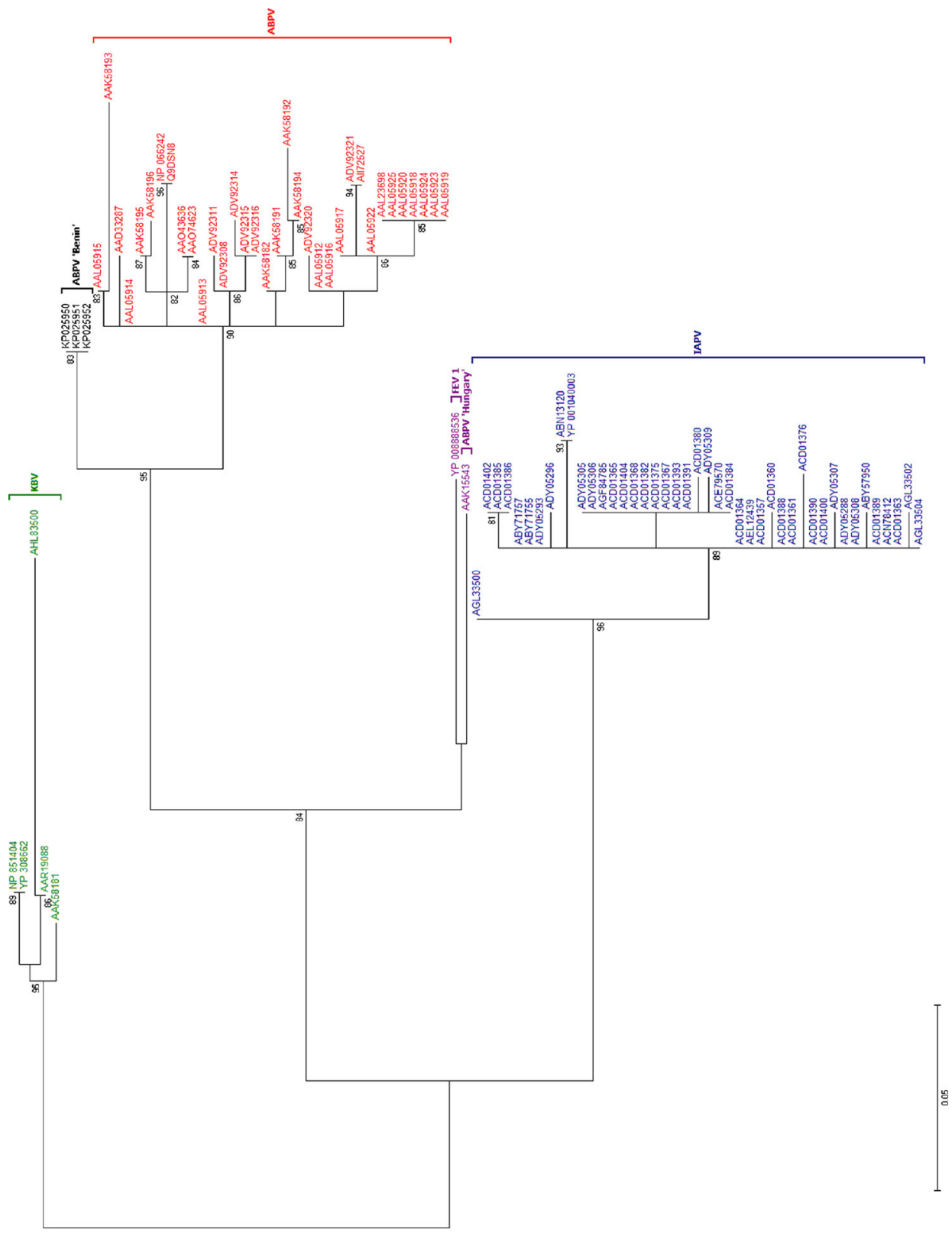

클

ธ

केo

$\Xi \frac{7}{3}$

.

焉

齐

ช

$\stackrel{0}{=}$

$\Xi$

F

츨

. 跔

㝕

学

产文

ज्ञ

ํㅗㄹ

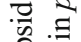

렁

.

일

E $\rightarrow \circ$

을

$>1$

过

岂

वै के

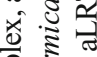

ิㅡㅇ

8 可

$>$ 㐨

远

胥焉

ีㅡㄴ 증

\%

离 Đ

要

苛焉

过导

艺氙

घ

颌

음

表. 虽

ल 跑安

总空壱 


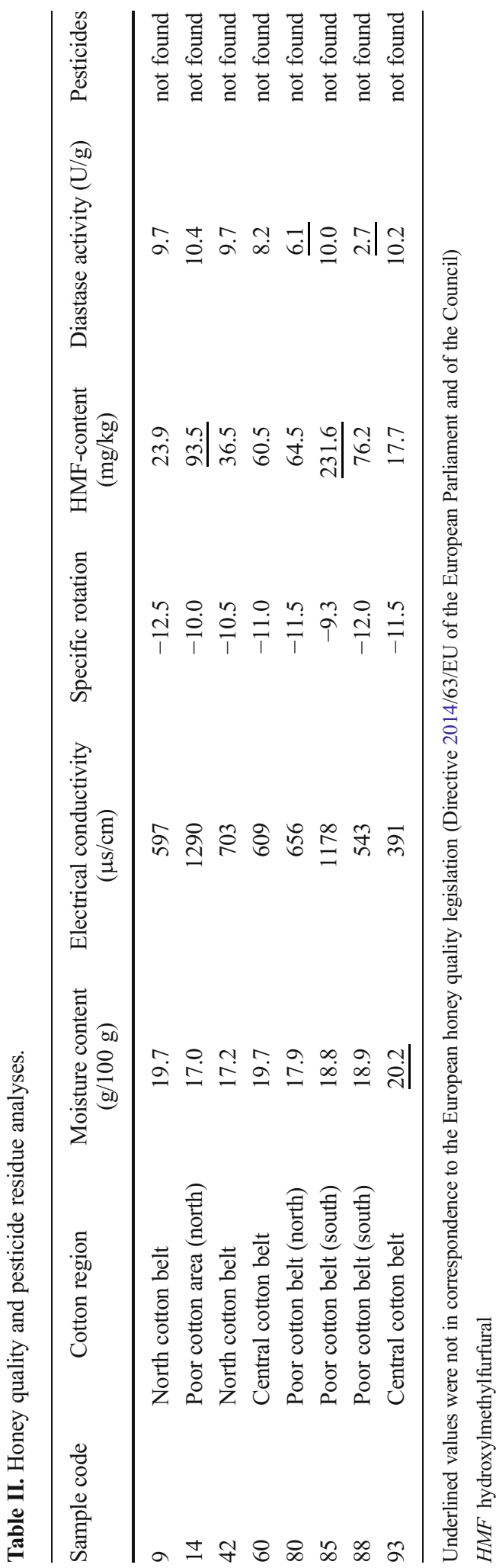

low when compared to the European, American and Asian situations, where up to $80 \%$ of the colonies were virus positive (Choe et al. 2012; De Smet et al. 2012; Tentcheva et al. 2004). We believe that this is due (as for the fungal, microbial and parasitic mites diseases) to the very low apiary density and a widespread beekeeping system based on natural swarms and in which the beekeepers will remove all the broods and combs from the hive during the harvesting periods, interrupting the life cycle of many diseases.

With respect to the virus species, our data confirm earlier reports that BQCV and ABPV are the most commonly found in the African continent (Swart et al. 2001; Kajobe et al. 2010; Strauss et al. 2013; Muli et al. 2014). The dominance of BQCV was found in European apiaries as well (Antunez et al. 2006). However, the finding of three samples that were positive for LSV was remarkable. It concerns a newly found bee virus and its discovery was thus far limited to only the USA and Europe (Runckel et al. 2011; Ravoet et al. 2013; Granberg et al. 2013). It seems to be a polymorphic viral species that also occurs in solitary bees (Ravoet et al. 2014). The finding of an ABPV with an unusual molecular signature of the capsid region is in line with the expectations, as different closely related bee viruses, including $\mathrm{ABPV}, \mathrm{KBV}$ and IAPV, are now considered part of a complex within the family of Dicistroviridae (de Miranda et al. 2010). Nevertheless, the taxonomic position of the found ABPV strain as intermediate between ABPV and IAPV could be evolutionary of importance, considering the isolation of the apiaries from Benin. Previously, a deviating ABPV strain (Genbank: AAK15543) was also detected in Hungary. Later on, it appeared to be related to a virus isolated from the ant Formica exsecta (Johansson et al. 2013). This might indicate that unusual viruses from the ABPV complex are present in Hymenopteran insects, but are only rarely detected.

Cotton is the main annual crop in the Republic of Benin, and pesticides in the categories of herbicides, fungicides, insecticides and acaricides are used. From the period of 2005 to 2015, the "Comité National d'Agrément et de Contrôle des Produits Phytopharmaceutiques" (CNAC) adopted a list of 64 pesticides that were allowed for use in the country (Table S1). We assumed that 
those pesticides may be found in honey samples from the different agro-regions where cotton culture is well developed. However, the results demonstrated that all samples were free from pesticide residues. In fact, this means that the honey samples even correspond to the Regulation (EC) 396/ 2005, as well as Regulation (EC) 470/2009 in conjunction with Commission Regulation (EU) $37 / 2010$ as far as pesticide residues from apicultural use are concerned. These results could be explained by the fact that initial concentrations of pesticides in nectar are lowered considerably by the bees (Schur and Wallner 2000) and many of the pesticides used today are unstable and disintegrate quickly after use (Bogdanov 2006). Furthermore, in West Africa, honey bees mainly collect nectar during the dry season when the usage of pesticides is limited. Finally pesticides show more affinity to beeswax compared to honey (Ravoet et al. 2015).

The high HMF and the low diastase activity in two honey samples could be explained by the long storage at room temperature (average of $32{ }^{\circ} \mathrm{C}$ ) between sampling and analysis.

In conclusion, the present study did not reveal any major threats or diseases listed by the International Office of Epizooty. Thus, there is a great opportunity for the beekeeping development in the strategies of poverty alleviation in the Republic of Benin. Though the viral infection level is still very low, it provided new data on the spread of recently discovered bee viruses in this unexplored western part of the African continent.

\section{ACKNOWLEDGMENTS}

This research was made possible with the kind support of the International Foundation of Science (IFS), which founded all the field works. We also thank the NGO 'Cercle Nature et Développement' (CENAD) and the 'Centre Intégré d'Apiculture Tropicale' (CIAT), which trained the beekeepers and helped establish the apiaries from which the samples were taken.

Découverte du virus du lac du Sinaï et d'une souche inhabituelle du virus de la paralysie aiguë de l'abeille dans des ruchers de l'Ouest Africain

Apis mellifera scutellata / Bénin / maladies de l'abeille / virus / parasite / résidus de pesticides
Entdeckung von Lake Sinai Virus und eines ungewöhnlichen Stamms von Akutem Bienenparalysevirus in Bienenständen in Westafrika

\section{Honigbienen / Krankheiten / Parasiten / Viren / Pestizidrückstände}

\section{REFERENCES}

Adjare, S. (1990) Beekeeping in Africa. FAO Agricultural Service Bulletin 68/6, Rome

Amakpe, F. (2008) Beekeeping in the strategies of biodiversity conservation, desertification control and poverty alleviation in Benin: A monograph of the honey bees in the district of Djidja. MA-dissertation, University of Liège - Faculty of Agronomy Sciences of Gembloux. Gembloux, Belgium

Amakpe, F., Akouehou, G.S., de Graaf D.C., Sinsin B. (2015) Determination of the silvo-melliferous regions of Benin: a nationwide categorisation of the land based on melliferous plants suitable for timber production. J. Agr. Rural Dev. Trop. 116(2)

Antunez, K., D’Alessandro, B., Corbella, E., Ramallo, G., Zunino, P. (2006) Honeybee viruses in Uruguay. J. Invertebr. Pathol. 93, 67-70

Bailey, L., Collins, M.D. (1982) Reclassification of 'Streptococcus pluton' (White) in a new genus Melissococcus as Melissococcus pluton nom. rev. comb. nov. J. Appl. Bacteriol. 53, 215-217

Bogdanov, S. (2006) Contaminants of bee products. Apidologie 37, 1-18

Brødsgaard, C., Hansen, H. (2003) Ondart bipest en verdensomspaedende sygdom. Tidsskr. Biavl 137 (7), 198-201

Choe, S.E., Nguyen, L.T.K., Noh, J.H., Koh, H.B., Hwa, J.Y., Kweon, C.H., Kang, S.W. (2012) Prevalence and distribution of six bee viruses in Korean Apis cerana populations. J. Invertebr. Pathol. 109, 330-333

Commission Regulation (EU) No 37/2010 of 22 December 2009 on pharmacologically active substances and their classification regarding maximum residue limits in foodstuffs of animal origin. Off. J. Eur. Union 2010 L15: 1-72

de Graaf, D.C., Alippi, A.M., Brown, M., Evans, J.D., Feldlaufer, M., Gregorc, A., Hornitzk, M., Pernal, S.F., Schuch, D.M.T., Titera, D., Tomkies, V., Ritter, W. (2006) Diagnosis of AFB in honey bees: a synthesis and proposed analytical protocol. J. Invertebr. Pathol. 92, 585-590

de Miranda, J.R., Cordoni, G., Budge, G. (2010) The acute bee paralysis virus-Kashmir bee virus-Israeli acute paralysis virus complex. J. Invertebr. Pathol. 103 (Suppl 1), $\mathrm{S} 30-\mathrm{S} 47$

De Smet, L., Ravoet, J., de Miranda, J.R., Wenseleers, T., Mueller, M.Y., Moritz, R.F.A., de Graaf, D.C. (2012) BeeDoctor, a versatile MLPA-based diagnostic tool for 
screening bee viruses. PLoS ONE 7 (10), e47953. doi:10.1371/journal.pone. 0047953

Denmark, H.A., Cromroy, H.L., Sanford, M.T. (2000) Honey bee tracheal mite, Acarapis woodi (Rennie) (Arachnida: Acari: Tarsonemidae). Entomology and Nematology Department, Cooperative Extension Service, Institute of Food and Agricultural Sciences, University of Florida

Directive 2014/63/EU of the European Parliament and of the Council of 15 May 2014 amending Council Directive 2001/110/EC relating to honey. Off. J. Eur. Union 2014 L164: 1-5

Ellis, J.D. (2004) The ecology and control of small hive beetles (Aethina tumida Murray). PhD-dissertation, Rhodes University

Ellis, J.D., Munn, P.A. (2005) The world health status of honey bees. Bee World 86, 88-101

Fakhimzadeh, K. (2001) Detection of major mite pests of Apis mellifera and development of non-chemical control of varroasis. PhD-dissertation, Department of Applied Biology University of Helsinki, Finland

Fries, I. (2002) African honey bees (Apis mellifera scutellata) and nosema (Nosema apis) infections. In Jones, R. eds. Bees without frontiers, Sixth European Bee Conference, Cardiff, UK

Gidey, A., Mulugeta, S., Fromsa, A. (2012) Prevalence of bee lice Braula coeca (Diptera: Braulidae) and other perceived constraints to honey bee production in Wukro Woreda, Tigray Region Ethiopia. Global Vet. $\mathbf{8}, 631-635$

Granberg, F., Vicente-Rubiano, M., Rubio-Guerri, C., Karlsson, O.E., Kukielka, D., Belak, S., SanchezVizcaino, J.M. (2013) Metagenomic detection of viral pathogens in spanish honeybees: co-infection by aphid lethal paralysis, Israel acute paralysis and lake sinai viruses. PLoS One 8(2), e57459. doi:10.1371/ journal.pone.0057459

Guindon, S., Dufayard, J.F., Lefort, V., Anisimova, M., Hordijk, W., Gascuel, O. (2010) New algorithms and methods to estimate maximum-likehood phylogenies: assessing the performance of PhyML 3.0. Syst. Biol. $\mathbf{5 9}, 307-321$

Hopping, M.E., Martyn, J.A.K., Hacking, N.J.A. (1993) Comparison of growth and yield of kiwifruit on different vine support structures. N. Z. J. Crop. Hortic. 295-301

Human, H., Pirk, C.W.W., Crewe, R.M., Dietemann, V. (2011) The honeybee disease American foulbrood: an African perspective. Afr. Entomol. 19(3), 551-557

IHC (2009) Harmonised methods of the International Honey Commission. URL http://www.bee-hexagon.net/en/ network.htm

Jacobs, F.J., Simoens, C., de Graaf, D.C., Deckers, J. (2006) Scope for non-wood forest products generation from rehabilitation areas: focus on beekeeping. J. Drylands 1, 171-185

Johansson, H., Dhaygude, K., Lindström, S., Helanterä, H., Sundström, L., Trontti, K. (2013) A metatranscriptomic approach to the identification of microbiota associated with the ant Formica exsecta. PLoS ONE 8(11), e79777. doi:10.1371/ journal.pone.0079777

Kajobe, R., Marris, G., Budge, G., Laurenson, L., Cordoni, G., Jones, B., Wilkins, S., Cuthbertson, A.G.S., Brown, M.A. (2010) First molecular detection of a viral pathogen in Ugandan honey bees. J. Invertebr. Pathol. 104, 153-156

Kearns, C.A., Inouye, D.W., Waser, N. (1998) Endangered mutualisms: the conservation of plant-pollinator interactions. Annu. Rev. Ecol. Syst. 29, 83-112

Klein, A.M., Vaissière, B.E., Cane, J.H., Dewenter, S.I., Cunningham, S.A., Kremen, C., Tscharntke, T. (2007) Importance of pollinator in changing landscapes for world crops. Proc. R. Soc. B 274, 303-313

Matheson, A. (1996) World bee health update. Bee World $77,45-51$

Morse, R., Calderone, N.W. (2000) The value of honey bees as pollinators of US crops in 2000. Bee Cult. 128, 1-15

Muli, E., Patch, H., Frazier, M., Frazier, J., Torto, B., Baumgarten, T., Kilonzo, J., Kimani, J.N., Mumoki, F., Masiga, D., Tumlinson, J., Grozinger, C. (2014) Evaluation of the distribution and impacts of parasites, pathogens and pesticides on honey bee (Apis mellifera) populations in East Africa. PLoS ONE 9(4), e94459. doi:10.1371/journal.pone.0094459

OIE. Terrestrial Animal Health Code (2009) Office International des Epizooties, URL http://www.oie.int/eng/ normes/Mcode.html

Paraïso, A., Cornelissen, B., Viniwanou, N. (2011) Varroa destructor infestation of honey bee (Apis mellifera adansonii) colonies in Benin. J. Apic. Res. 50(4), 321-322

Ravoet, J., Maharramov, J., Meeus, I., De Smet, L., Wenseleers, T., Smagghe, G., de Graaf, D.C. (2013) Comprehensive bee pathogen screening in Belgium reveals Crithidia mellificae as a new contributory factor to winter mortality. PLoS ONE 8(8), e 72443. doi:10.1371/journal.pone. 0072443

Ravoet, J., De Smet, L., Meeus, I., Smagghe, G., Wenseleers, T., de Graaf, D.C. (2014) Widespread occurrence of honey bee pathogens in solitary bees. J. Invertebr. Pathol. 122, 55-58

Ravoet, J., Reybroeck, W., de Graaf, D.C. (2015) Pesticides for apicultural and/or agricultural application found in Belgian honey bee wax combs. Bull. Environ. Contam. Toxicol. 94, 543-548. doi:10.1007/ s00128-015-1511-y

Regulation (EC) No 396/2005 of the European Parliament and of the Council of 23 February 2005 on maximum residue levels of pesticides in or on food of plant and animal and amending Council Directive 91/414/EEC. Off. J. Eur. Union 2005 L70: 1-16

Regulation (EC) No 470/2009 of the European Parliament and of the Council of 6 May 2009 laying down Community procedures for the establishment of residue limits of pharmacologically active substances in foodstuffs of animal origin, repealing Council Regulation (EEC) No 2377/90 and amending Directive 2001/82/EC of the 
European Parliament and of the Council and Regulation (EC) No 726/2004 of the European Parliament and of the Council laying down a Community procedure for the establishment of maximum residue limits of veterinary medicinal products in foodstuffs of animal origin. Off. J. Eur. Union 2009 L152: 11-22

Roubik, D.W. (1995) Pollination of Cultivated Plants in the Tropics. Food and Agriculture Organization of the United Nations, Rome

Runckel, C., Flenniken, M.L., Engel, J.C., Ruby, J.G., Ganem, D., Andino, R., DeRisi, J.L. (2011) Temporal analysis of the honey bee microbiome reveals four novel viruses and seasonal prevalence of known viruses, Nosema, and Crithidia. PLoS One 6(6), e20656. doi:10.1371/journal.pone.0020656

Sanford, M.T. (2003) Diseases and pests of the honey bee. CIR766, Entomology and Nematology Department, Florida Cooperative Extension Service, Institute of Food and Agricultural Sciences, University of Florida

Schur, A., Wallner, K. (2000) Bewertung des individuellen Wirkstoffeintrages von Sammelbienen nach Pestizidapplikation in blühende Kulturen. Apidologie 31, 615-616
Singh, R., Levitt, A.L., Rajotte, E.G., Holmes, E.C., Ostiguy, N., Vanengelsdorp, D., Lipkin, W.I., Depamphilis, C.W., Toth, A.L., Cox-Foster, D.L. (2010) RNA viruses in hymenopteran pollinators: evidence of inter-Taxa virus transmission via pollen and potential impact on non-Apis hymenopteran species. PLoS One 5, e14357

Strauss, U., Human, H., Gauthier, L., Crewe, R.M., Dietemann, V., Pirk, C.W.W. (2013) Seasonal prevalence of pathogens and parasites in the savanah honeybee (Apis mellifera scutellata). J. Invertebr. Pathol. 114, 45-52

Swart, D.J., Johannsmeier, M.F., Tribe, G.D., Kryger, P. (2001) Diseases and pests of honeybees. In: Johannsmeier, M.F. (ed.) Beekeeping in South Africa, 3rd edn. Plant Protection Handbook No. 14. Agricultural Research Council, Pretoria

Tentcheva, D., Gauthier, L., Zappulla, N., Dainat, B., Cousserans, F., Colin, M.E., Bergoin, M. (2004) Prevalence and seasonal variations of six bee viruses in Apis mellifera L. and Varroa destructor mite populations in France. Appl. Environ. Microbiol. 70, 7185-7191 